\title{
INFLUENCE OF ORGANIZATIONAL FORMS OF PRODUCTION AND BUSINESS ON THE INNOVATIVE ECONOMIC DEVELOPMENT
}

\author{
Kabir R. Saubanov ${ }^{1}$ \\ Mikhail V. Nikolaev ${ }^{2}$
}

\begin{abstract}
The article is devoted to the analysis of the influence of new organizational forms of production and business arising in the course of economic evolution on the development of innovative processes. We used the methods of abstract-logical approach, comparative and historical-economic analysis. The study was conducted on the example of the Russian economy in comparison with other countries. We considered various organizational forms:
\end{abstract} technoparks; business incubators; network and shell companies, etc. It is shown that there is no uniform, universal and effective form for all cases. They all require additional forms in relation to themselves, which expand the possibilities for the development of innovations. We analyzed the trend to "idealize" the organizational systems, meaning their desire to reduce the number of employed personnel to a minimum and to reduce the amount of intra-organizational costs. The conducted research allows asserting that the development of economic systems and forms of production and business organization leads to a change in their economic and institutional structure and causes a tendency to expanding the organizational diversity. At the same time, the determining principle of the development of modern forms of production and business organization is their complementarity with respect to each other. The obtained results can be used in practice of economic activity and management, including when choosing the organizational forms most effective in terms of opportunities and prospects for the innovative development.

Keywords: organizational systems; organizational forms; innovation; integration.

\footnotetext{
${ }^{1}$ Kazan (Volga) Federal University, 18, Kremlevskaya Str., Kazan, Russia, 420008.

${ }^{2}$ Kazan Cooperative Institute, 58, NikolayaErshova Str., Kazan, Russia, 420045.
} 


\section{Introduction}

There are continuous changes and the emergence of new organizational systems of production and management, which are integral and interconnected systems of cultural, economic, technological and spatial components, giving a specific structural order to the intra-organizational, intra-corporate or in-firm events in the process of economic evolution, including the development of technical and economic systems and technologies. This process leads to the economy saturation with numerous organizational forms of production and business from the individual entrepreneurs and small enterprises to the large industrial and commercial agglomerations and transnational corporations. At the same time, each of them influences the development of innovative processes in its own way, and because of the high level of the external environment dynamics, it cannot function under any conditions with the same efficiency. For example, the advantage of large enterprises is the ability to organize mass production and achieve savings by scale, but at the same time they have difficulty in ensuring an effective innovation process. It is
Periódico do Núcleo de Estudos e Pesquisas sobre Gênero e Direito Centro de Ciências Jurídicas - Universidade Federal da Paraíba V. 8 - No 05 - Ano 2019 ISSN | 2179-7137 | http://periodicos.ufpb.br/ojs2/index.php/ged/index

sometimes preferable for economic entities to even transfer some of their functions to state structures, for example, in the sphere of basic research and development and in the social sphere, in order to gain additional benefits from reducing the overall duration of the innovation cycle.

A new role in the activation of innovative processes, in comparison with the previous stages, is currently inherent in small and medium-sized businesses of developed countries with a market economy, where it has actually assumed the functions of a conductor of organizational and technological changes. This is due primarily to the total spread of microelectronics, equalizing the technological capabilities of small and large-scale production and business [1].

Strictly speaking, there is no single effective and sustainable form of production and business organization. In all cases, as a rule, the additional organizational forms are required in relation to the initial ones, which expand the opportunities for using new technologies, which create new innovative competitive advantages through the innovations of various types [2]. 


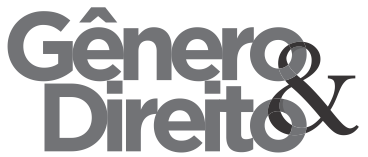

This pattern is clearly seen in the functioning of market systems in Western countries, when new principles of interaction between the small and large-scale production in the United States and some European countries began to take shape based not on competition but on mutually beneficial cooperation in the last decades of the XX century.

Such an additional relationship of organizational forms with respect to each other is also developed in the modern Russian economy, manifesting itself in new forms of public-private partnership that allow providing a systemic effect in increasing the innovation activity of the economy.

Thus, based on the above, the problem of influence of the organizational forms of production and business on the innovative development of the economy is urgent and requires new additional research.

The purpose of this article is to identify the main elements of the mechanism of influence of new organizational forms of production and business on the development of innovation process that promote its activation and improvement.
Periódico do Núcleo de Estudos e Pesquisas sobre Gênero e Direito Centro de Ciências Jurídicas - Universidade Federal da Paraíba V. 8 - No 05 - Ano 2019 ISSN | 2179-7137 | http://periodicos.ufpb.br/ojs2/index.php/ged/index

\section{Methods}

The methods of abstract-logical approach, which includes scientific abstraction and theoretical conclusions, was used to study the content of organizational forms of production and business and their interrelations with the processes of innovation development.

The method of comparative analysis was used to divide common and distinctive features of the processes of forming the organizational forms and their impact on the innovative development of the economy in the economic systems - Russia, the United States, and European countries.

The method of historical and economic analysis was used to study the patterns of the emergence, development and change of organizational forms of production and business in the context of their impact on the activation of innovation activities.

\section{Results}

The studies have shown that the main direction of interaction of production organizational forms with the activation of innovative processes in today's post-industrial economies is the integration of large and small economic structures. At the same time, the 


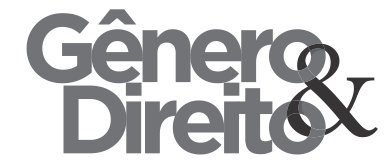

Periódico do Núcleo de Estudos e Pesquisas sobre Gênero e Direito

Centro de Ciências Jurídicas - Universidade Federal da Paraíba

V. 8 - $\mathrm{N}^{\circ} 05$ - Ano 2019

ISSN | 2179-7137 | http://periodicos.ufpb.br/ojs2/index.php/ged/index integration is not the same in Western countries and in Russia as the mechanisms of this process in market systems have evolved in the course of natural economic evolution, and they are more borrowed, transferred in a readymade form in Russia.

By itself, such borrowing is a normal and inevitable phenomenon, allowing minimizing the time required for their formation. At one time, various economic and political forms, structures and institutions were also exported from the USSR to various states.

At the same time, this interaction is not simple and contradictory. And sometimes it causes the results opposite to the supposed ones. This is evidenced, for example, by the experience of uncritical borrowing of "Western" management forms by Russian joint-stock companies, which has led, due to insufficiently effective and incompletely formed antimonopoly legislation, to ignoring the interests of numerous small investors by large shareholders-insiders.

Moreover, the non-critical import of organizational forms often leads to an overly broad and contradictory interpretation of their content, thereby complicating the possibility of their immediate positive use.

An example would be an understanding of such an organizational form, popular in many countries, directly related to the activation of innovation activities, such as a technopark in Russia. The first technopark, as is known, was created in the 1940s in the USA on the basis of Stanford University. All the future features of this organizational form have already been seen in its structure, which has become a key element of national innovation systems. Several dozen square kilometers of land plots belonging to the university, began to be leased only to high-tech and, most often, small companies for the creation of production facilities and offices [3]. In particular, Eastman Kodak, General Electric, Hewlett-Packard opened their representative offices among the first ones. As a result, it appeared the university's cooperation with a network of enterprises, united by a single goal of commercialization of scientific and technical innovation ideas and developments. In Russia, the technoparks began to be created since 1990. The dynamics of this process is very high, as can be seen from the following graph: 


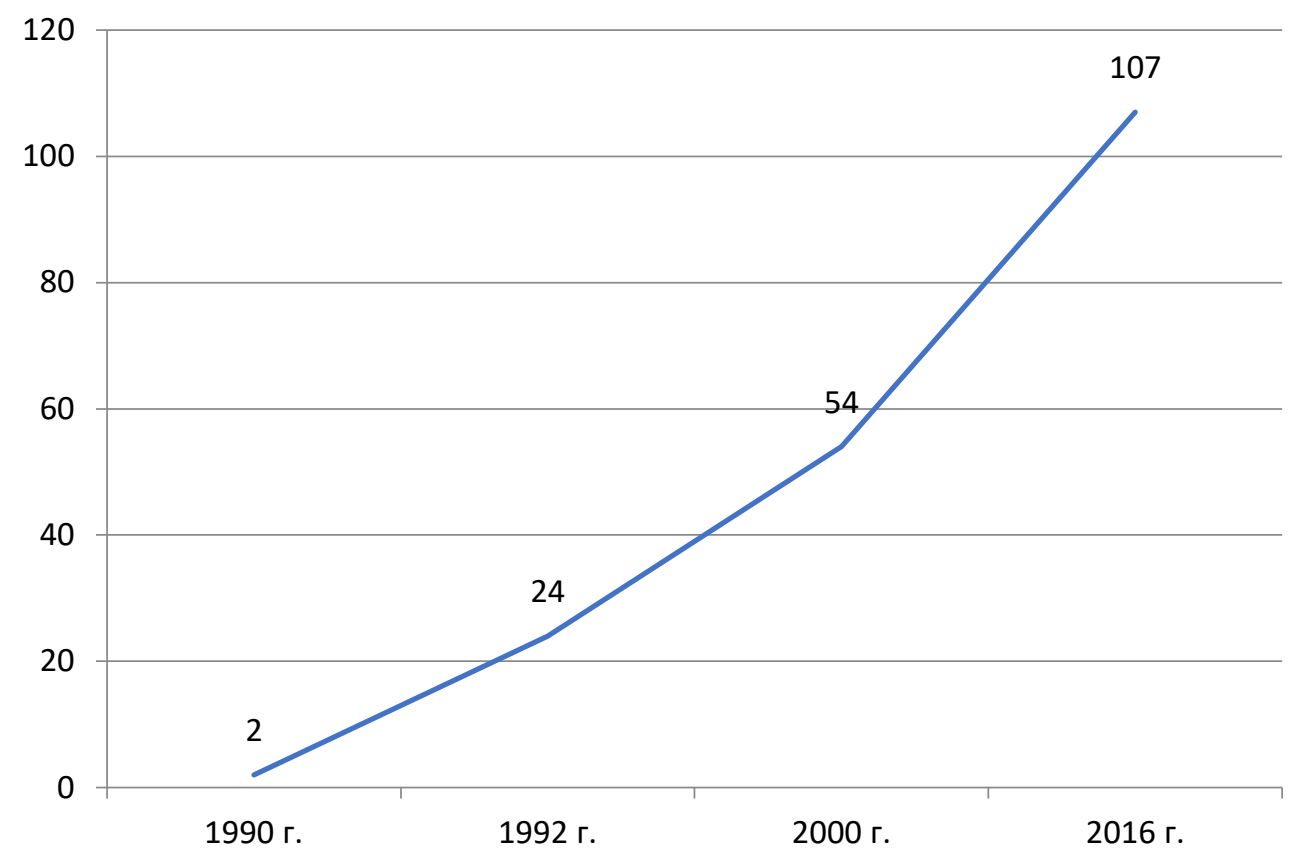

Fig. 1.The dynamics of technopark development in the Russian Federation for the period of 1990-2016. Note: Compiled by the author

The number of technoparks in Russia has increased from 2 in 1990 to 107 in 2016. It should be noted that, strictly speaking, the task of supporting small businesses as such has never been specifically set in the framework of a classical technopark. The task was different - to ensure the competitiveness of innovative ideas, rather than small businesses. The same assistance that was given to small businesses through the creation of a single infrastructure, again not for the sake of these enterprises, but for the same commercialization of results based on high-tech innovative solutions.
However, under the conditions of the Russian economy, the concept of a technopark often began to be invested with a different meaning, reminding of the forms of territorial integration of production and business. According to N.V. Rodionova, for example, the technopark is a scientific and industrial territorial complex, which is formed in order to create an enabling environment for the development of small and medium-sized science-intensive innovation firms [4]. She believes that the technopark produces not only the market-demanded new technologies, but also some small innovative enterprises. 


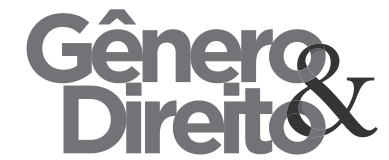

Periódico do Núcleo de Estudos e Pesquisas sobre Gênero e Direito

Centro de Ciências Jurídicas - Universidade Federal da Paraíba

V. 8 - No 05 - Ano 2019

ISSN | 2179-7137 | http://periodicos.ufpb.br/ojs2/index.php/ged/index
A similar point of view was expressed by other authors, for example, A.V. Surin and O.P. Molchanova [5]. Thus, the goal of such technoparks, unlike the classical western ones, is different and, perhaps, more inherent not in the technoparks, but in the business incubators.

In general, the allocation of technoparks and business incubators with the same functions and purposes is not uncommon in the Russian economic practice. There are also some statements that the technopark is the result of the development of business incubator idea, although such an assertion contradicts the facts, since the prototype of the first business incubator appeared only in 1959 in the USA in the works of J. Mankuso, i.e. 19 years after the first technopark [6].

The specific meaning is invested In Russia in such notion and form of business and production integration as a technopolis, which is often seen as a result of the development of technopark idea [5], which also contradicts the facts, as the technopolises - science cities, scientific towns (Dubna, Pushchino, Obninsk and others)- have been also developed in the Soviet Union without any technoparks.

In the middle of 2000 , the term "techno-park structures", which was extended to all new organizational forms, was started to be used, possibly to mitigate these contradictions, which also seemed not entirely legitimate, since each of them had its own content.

The next important development of organizational forms of production and business is the shift in emphasis in this area from the federal level to the regional one. In particular, this is evidenced by the fact that the first rating group consisting of 10 leading technoparks of the Russian Federation with activity indicators exceeding the Russian average by $10 \%$ to this date, as follows from the table below, along with the technoparks in Moscow, includes the technoparks of the republics and regions of the country:

Table 1:Technoparks of the highest rating group of the Russian Federation, 


\begin{tabular}{|l|l|l|}
\hline $\begin{array}{c}\text { Ser. } \\
\text { No. }\end{array}$ & \multicolumn{1}{|c|}{ Name of technopark } & \multicolumn{1}{|c|}{$\begin{array}{c}\text { Geographical } \\
\text { location of the } \\
\text { technopark }\end{array}$} \\
\hline & Nanotechnological Center "Technospark" & Moscow \\
\hline & MSU Science Park & Moscow \\
\hline & Scientific and technological park of Novosibirsk & Novosibirks Region \\
\hline & Technopolis "Moskva" & of \\
\hline & $\begin{array}{l}\text { Technopark "Strogino" } \\
\text { Innovation and production technopark "Ideya" }\end{array}$ & $\begin{array}{l}\text { Republic } \\
\text { Tatarstan }\end{array}$ \\
\hline & $\begin{array}{l}\text { Autonomous Institution "TechnoparkMordovia" } \\
\text { Park" }\end{array}$ & $\begin{array}{l}\text { Republic } \\
\text { Mordovia }\end{array}$ \\
\hline & $\begin{array}{l}\text { State Autonomous Institution of the Tyumen Region } \\
\text { "West-Siberian Innovation Center" }\end{array}$ & Tyumen Region \\
\hline & Tlyanovensk Region \\
\hline
\end{tabular}

Source: Industry news: Russia. - URL: http://www.ruscable.ru/news/russia/

Table 1 shows that 1 technopark in the Novosibirsk Region, 2 - in the Republic of Tatarstan, 1 - in the Republic of Mordovia, Ulyanovsk and Tyumen Regions are in the 1st rating group, apart from 4 technoparks in Moscow.

The process of shifting the emphasis towards the regions began about 10 years ago. According to M.I. Dli and T.V. Kakatunova [7], this is due to the need to take into account the regional specifics in the allocation of priority areas of investment policy. At the same time, the effectiveness of implementing the relevant programs and projects is related to the possibilities of creating innovative regional infrastructures as separate subsystems of the entire national innovation system as a whole [8].

The same shift in emphasis is indicated by the structure of ownership 


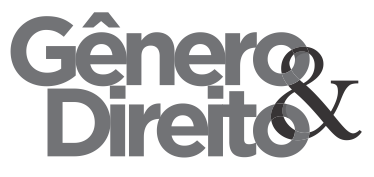

Periódico do Núcleo de Estudos e Pesquisas sobre Gênero e Direito

Centro de Ciências Jurídicas - Universidade Federal da Paraíba

V. 8 - $\mathrm{N}^{\circ} 05$ - Ano 2019

ISSN | 2179-7137 | http://periodicos.ufpb.br/ojs2/index.php/ged/index of Russian technoparks, in which, as we see in Fig. 2, the regional administrations dominate. They account for $39 \%$ of the total gross amount of funds allocated to support the technology parks.

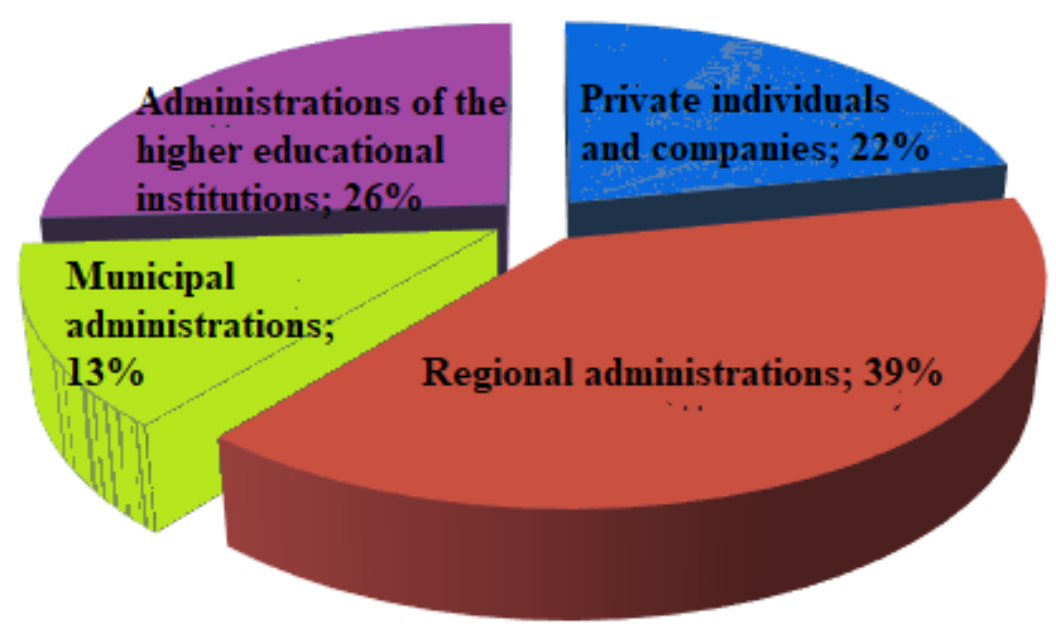

Fig. 2. Owners of Russian technoparks

Source: Khaykina E. M, Sizova Yu. S. Development of Technoparks in the Russian Federation // Young Scientist. - 2016. - No. 14. - P. 409-412.

As the third direction of the influence of organizational forms of production and business on innovative development, one can consider the "idealization" of organizational systems, consisting in their striving for comprehensiveness, minimizing the number of personnel involved in them and reducing the amount of internal organizational costs.

Thus, at the level of a firm or enterprise, some of the functions inherent in the organizational system can be transferred to other neighboring supersystems or subsystems. The examples of such processes are the formation of network and shell firms. In the first ones, the entire technological process is dismembered between small business structures, and the administrative apparatus is usually represented only by the entrepreneurowner, which is an industrialmanagement innovation. And in the shell 


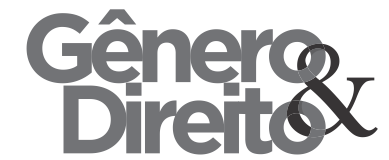

firm, on the contrary, the management apparatus is preserved, but the production link, whose role is transferred to subcontractors, is eliminated, which opens up new opportunities for technological and economic innovations [9].

A similar process of moving away from the self-sufficient multifunctional economic systems is also observed at the macro level. Here it manifests itself in a narrow country specialization, for example, on the peripheral states - in the export of agroindustrial products or raw materials, and in the developed Western countries - in the production and export of high technology.

\section{Discussion}

All of the above indicates that the development of organizational forms is intertwined with the processes of institutionalization of a number of economic functions related to the scientific research, education, health care, etc. This leads to a qualitative complication of organizational systems and the strengthening of the importance of human factor in the activation of innovative processes.
Periódico do Núcleo de Estudos e Pesquisas sobre Gênero e Direito

Centro de Ciências Jurídicas - Universidade Federal da Paraíba

V. 8 - No 05 - Ano 2019

ISSN | 2179-7137 | http://periodicos.ufpb.br/ojs2/index.php/ged/index

382

The improvement of

organizational systems and their impact on the innovative development of the economy is a multifactor process and it is expedient to use the models that have been formed to date, for example, the transactional $[10 ; 11]$ and institutional ones [12], to discuss it.

The first of them is based on the ideas of R. Coase and allows arguing that the firms as specific institutions are called upon to minimize the uncertainty of external environment, which in itself is an incentive for the integration of production and business and the formation of new organizational structures.

The second one helps to answer the question, for what reasons different organizations take strictly defined forms, explaining this fact with the idea of "institutional isomorphism". Any organizational and economic structure, according to this model, is in the organizational field of other organizations surrounding it, which gradually makes them more and more similar.

\section{Summary}




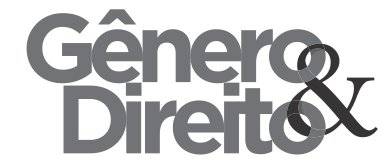

The research conducted makes

it possible to draw a number of conclusions.

1. The ways and mechanisms of the influence of different organizational forms of production and business on innovative processes are not the same. Large economic structures tend to seek benefits for themselves through a general reduction in the innovation cycle duration. While it is more typical for small ones to specialize in the development of individual stages of this cycle that are most appropriate for their production and financial conditions, secondly, their behavior is largely determined by the general state of the surrounding organizational environment of the economic system and trends in the development and improvement of its technological basis, directly determining the capabilities of these structures and their role in the innovation process.

2. The main direction of activating the innovative processes in the economy is currently connected, on the one hand, with the continuing trend towards the growing development of organizational diversity, and on the other hand, with the consistent implementation of the principle of complementarity of various organizational forms relative to
Periódico do Núcleo de Estudos e Pesquisas sobre Gênero e Direito

Centro de Ciências Jurídicas - Universidade Federal da Paraíba

V. 8 - No 05 - Ano 2019

ISSN | 2179-7137 | http://periodicos.ufpb.br/ojs2/index.php/ged/index

each other, which is an integral feature of modern production and business in a rational combination of mutually exclusive classes of formed organizational forms.

3. The principle of complementarity determines the effectiveness of functioning of the organizational systems and their innovative activity primarily in the conditions of today's highly competitive environment, which is characterized by a greater degree of uncertainty and risk. It operates at all levels of the economic system. It facilitates the formation of large vertically integrated corporations at the micro level. It determines the emergence of special laboratories and venture firms at the meso level, through the intra-industry affiliation of corporations. At the macro level, it gives rise to the institutionalization of a number of functions of economic entities.

4. The trend toward the development of organizational diversity is limited by the phenomenon of institutional isomorphism. Therefore, a specific complex and sometimes contradictory picture of the state of organizational forms of production and business and their impact on innovative 


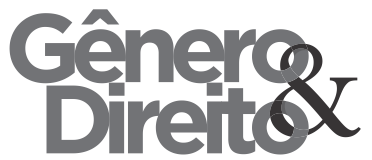

development at each stage is determined

by the resultant of two named processes.

\section{Acknowledgement}

The work is performed according to the Russian Government Program of Competitive Growth of Kazan Federal University.

\section{References}

M.V. Nikolaev, K.R. Saubanov, «On the role of small business in the Development of economic systems», Journal of Economics and Economic Education Research, vol. 17, No. 4, pp. $105-111,2016$.

M. Postalyuk, A. Akhmetshina, «Innovation structures a sustainable development of economic systems». Investment Management and Financial Innovations, vol. 11, Issue 4, pp. 127133, 2014.

Technoparks of the World and Russia. URL: https://geektimes.ru/post/291331/ [4] RodionovaN.V. External Effects due to the Technopark Activity // Innovations. 2008. - No. 3 (113). - P. $62-65$.
Periódico do Núcleo de Estudos e Pesquisas sobre Gênero e Direito Centro de Ciências Jurídicas - Universidade Federal da Paraíba V. 8 - No 05 - Ano 2019 ISSN | 2179-7137 | http://periodicos.ufpb.br/ojs2/index.php/ged/index

SurinL.V., MolchanovaO.P. Innovative Management. - M.: INFRA-M, 2008. $368 \mathrm{p}$.

How did the First Business Incubator Emerge? - URL: http: // biznespraktik.ru

DliM.I., KakatunovaG.V. On the Prospects of Creating Technopark Structures of a Network Type // Innovations. - 2008. - No. 2 (112). - P. 118-120.

Y. Khalabuda, M. Nikolaev. «Managing competitiveness of the region through innovation».Saarbrucken, Deutschland: Lap Lambert Academic Publishing, 2013.

Y. Khalabuda, M. Nikolaev, «Increase of efficiency of industrial enterprises activity on the basis of innovations of various types», Procedia Economics and Finance, vol 16, pp. 299 - 302, 2014.

R.H. Coase, «The Nature of the Firm». Economica, New Series, Vol. 4, Issue 16, pp. 368-405, 1937. 
Periódico do Núcleo de Estudos e Pesquisas sobre Gênero e Direito Centro de Ciências Jurídicas - Universidade Federal da Paraíba V. 8 - No 05 - Ano 2019 ISSN | 2179-7137 | http://periodicos.ufpb.br/ojs2/index.php/ged/index

O.E. Williamson, «The Economic

Institutions of Capitalism». New York:

Free Press. 1985.

DiMaggio P., Powell W., «The Iron

Cage Revisited: Institutional

Isomorphism and Collective Rationality

Organizational Fields». American

Sociological Review, Vol. 48, N 2, -

pp.147-160, 1983 